\title{
Radon in the Ground Water of Chester County, Pennsylvania
}

\section{Introduction}

A study of the occurrence and distribution of dissolved radon in the ground water of Chester County was undertaken by the U.S. Geological Survey (USGS) in cooperation with the Chester County Water Resources Authority and the Chester County Health Department. The results of this study are published in a technical report by Senior (1998). This fact sheet summarizes the key findings presented in the technical report. Much of the background information on radon was taken from Lindsey and Ator (1996).

\section{What is Radon?}

Radon is a naturally occurring, colorless, odorless gas that is soluble in water. It is produced through the radioactive decay of uranium and radium, which is naturally present in soil and in minerals in bedrock. Radon is radioactive, which means that it breaks down or "decays" to form other elements. The rate of radon's radioactive decay is defined by its half-life, which is the time required for one half of the amount of radon present to break down to form other elements. The half-life of radon is 3.8 days. A common unit of radioactivity measurement is picocuries per liter. One picocurie per liter is about equal to the decay of two atoms of radon per minute in each liter of air or water. This fact sheet refers to the amount of radon measured in air or water in picocuries per liter as the radon concentration.

Radon concentrations generally differ among different rock types and can vary considerably within the same geologic formation. Radon moves from its source in rocks and soils through voids and fractures. It can enter buildings as a gas through foundation cracks or it can dissolve in ground water and be carried to buildings through the use of water-supply wells.

\section{Why Study Radon?}

The Surgeon General of the United States has recognized exposure to radon gas as being second only to cigarette smoking as a cause of lung cancer (U.S. Environmental Protection Agency, 1992). Radon gas can cause lung cancer if inhaled because its decay products can accumulate in the lungs and damage lung tis-

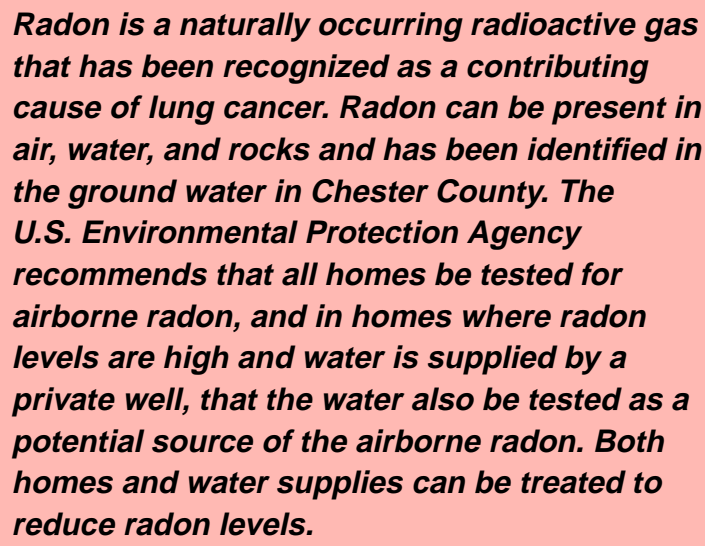

sue. As radon decays, it produces several short-lived elements that also are radioactive. Radon, together with these decay products, emits alpha particles that can damage lung tissue. Although most radon is exhaled before it can do much damage, the decay products can remain trapped in the respiratory system attached to dust, smoke, and other fine particles from the air. Eventually, the accumulation of these radioactive elements in constant, close contact with lung tissue can cause cancer. Ingestion of radon also may cause health problems (Crawford-Brown, 1990; Mills, 1990).

While radon gas commonly enters the air in homes through basements, ground water can carry additional radon into homes and other buildings, increasing the health risk associated with radon in the air. Dissolved radon is easily released into the air when the water is used for showering, cleaning, and other everyday purposes (fig. 1). Milry and Cothern (1990) estimate the degassing of

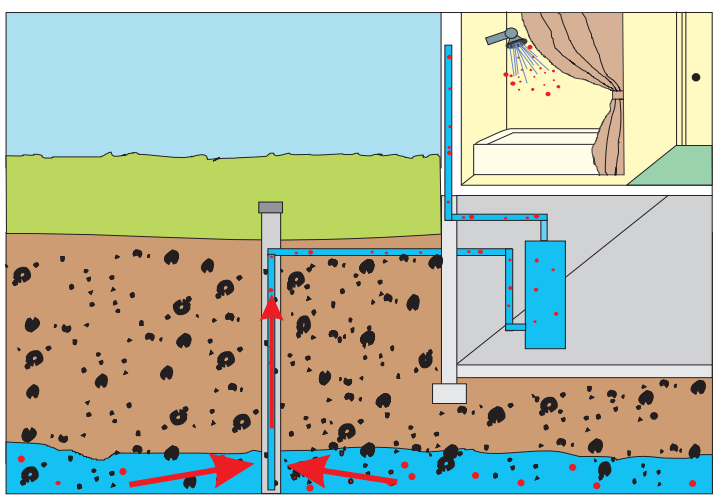

Figure 1. Radon entering a home through the water system (Modified from Otton, 1992, by Lindsey and Ator, 1996).

radon adds $1 \mathrm{pCi} / \mathrm{L}$ (picocuries per liter) to air for each 10,000 pCi/L in water. In homes built with better insulation and better seals on windows and doors, radon has less chance to be ventilated to the outside and can become concentrated to dangerous levels in indoor air. Most radon escapes from the water at the faucet or other point of use, leaving little in the water itself. The radon that escapes from the water adds to the radon that enters the home through the basement, and, in some cases, the water may contribute a large part of the radon that is present in a home. A study by Mose and others (1990) found that cancer occurrences increase as the amount of radon in household water increases. The U.S. Environmental Protection Agency (USEPA) has not yet established a Maximum Contaminant Level (MCL) for radon in drinking water.

Water-borne radon commonly is a concern only for those who use well water for their water supply. In 1990, about 35 percent of the population of Chester County (approximately 130,000 people) relied on ground water from individual home wells as a source of water supply (Chester County Planning Commission, 1996). 
Because of its short half-life, radon in some public water supplies utilizing ground water may decay to low concentrations before the water is delivered to users, especially if the water has been treated. Also, public suppliers commonly use surface-water supplies, which generally have very low radon concentrations (Zapecza and Szabo, 1988).

\section{Where Did We Test for Radon?}

Since 1986, analysis for radon has been a standard component of ground-water-quality studies conducted by the USGS in cooperation with the Chester County Water Resources Authority and the Chester County Health Department. Water samples collected from November 1986 through September 1996 from 534 wells in Chester County were analyzed for radon for studies done in cooperation with Chester County and Commonwealth of Pennsylvania agencies. Most wells sampled were household wells equipped with submersible pumps. Samples were collected from the household plumbing system, and, if present, filters or treatment systems were bypassed.

Water samples from all major geologic units in Chester County were analyzed for radon. The geologic units that underlie the county have been grouped into six geohydrologic groups (Sloto, 1994) on the basis of similar geologic, water-bearing, and ground-water-flow system characteristics (except for group six). These groups are (1) Triassic-age sedimentary rocks (Stockton Formation, Hammer Creek Formation, and other sandstone, shale, and conglomerate units), (2) carbonate rocks (Conestoga Limestone and other limestone, dolomite, and marble units), (3) quartzite rocks (Chickies Quartzite and Setters Formation), (4) schist and phyllite (including Octoraro Phyllite, Peters Creek Schist, and Wissahickon Schist), (5) gneiss, and (6) all other rocks (including ultramafite/serpentinite) (fig. 2). The last geohydrologic group (all other rocks) includes geologic units of small areal extent that are not important water-bearing

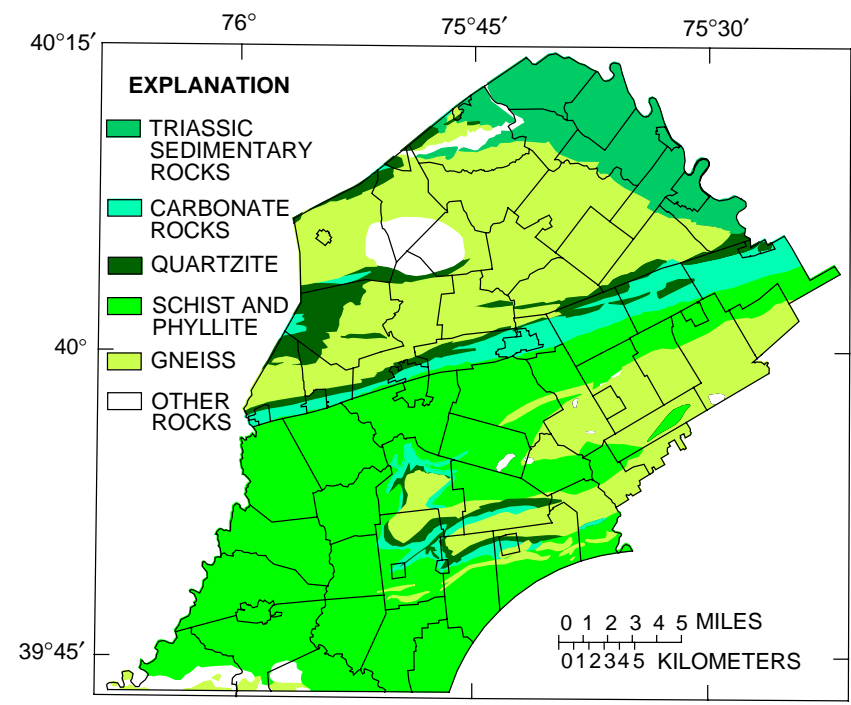

Figure 2. Generalized geologic map of Chester County showing geohydrologic groups.

units, are intrusive rocks, or do not fit into other categories.

The sample distribution in the 759-square-mile county averaged one per 1.4 square miles, although the distribution was not areally uniform because some geologic units were sampled more extensively for previous studies. Sample density also varied among geologic units, and a few units were not sampled because of their small areal extent. In addition, 28 wells were sampled more than once, including 1 well sampled monthly for 3 years, 4 wells sampled quarterly for 1 year, and 5 wells sampled bi-monthly for more than 1 year.

\section{What Did We Find?}

Ground-water samples collected from 1989 to 1996 were analyzed at the USGS National Water-Quality Laboratory in Arvada, Colo., and samples collected from 1986 to 1988 were analyzed at the University of Maine. Sample results were analyzed to determine patterns in the radon concentration among the geologic units of Chester County. Because the radon concentration in ground water from each geologic unit is highly variable, concentrations are reported as the median concentration. The median is the concentration at which half of the samples have a lower concentration and half have a higher concentration. Median radon concentrations are useful to draw general conclusions about the presence of radon in ground water in a particular geologic unit but should not be used to predict concentrations at specific sites.

A map of geologic units grouped by ranges in median radon concentrations in ground water is shown in figure 3 . Although this map is useful in assessing the general radon potential of ground water in each geologic unit, differences within a geologic unit are apparent when studied in more detail. For example, in southern Chester County, ground water in the northern part of the Wissahickon Schist contains higher median radon concentrations than ground water in the southern part of the Wissahickon Schist (Senior, 1996).

The lowest radon concentration measured was $50 \mathrm{pCi} / \mathrm{L}$, which is about equal to the laboratory's minimum reporting level for the analytical method. The median concentration was $1,500 \mathrm{pCi} / \mathrm{L}$. The maximum concentration measured was $53,000 \mathrm{pCi} / \mathrm{L}$. Water from about 60 percent of the wells sampled contained radon concentrations at or above $1,000 \mathrm{pCi} / \mathrm{L}$. This is higher than the study by Lindsey and Ator (1996), which reported that radon concentrations exceeded $1,000 \mathrm{pCi} / \mathrm{L}$ in water from 31 percent of wells sampled in the lower Susquehanna and Potomac River Basins. Water from about 12 percent of wells sampled in Chester County contained radon concentrations greater than $5,000 \mathrm{pCi} / \mathrm{L}$ and water from about 2 percent of the wells sampled contained radon concentrations greater than 10,000 pCi/L.

Radon concentrations differ by rock type. The geohydrologic groups with the highest median radon concentrations in ground water include schist and phyllite $(2,400 \mathrm{pCi} / \mathrm{L})$ and quartzite $(2,150 \mathrm{pCi} / \mathrm{L})$. The geohydrologic groups with lowest median radon concentrations in ground water include carbonate rocks $(540 \mathrm{pCi} / \mathrm{L})$ and other rocks (group 6) $(360 \mathrm{pCi} / \mathrm{L})$. Water from wells in gneiss had a median radon concentration of $1,000 \mathrm{pCi} / \mathrm{L}$, and water from wells in Triassic-age sedimentary rocks had a median radon concentration of $1,300 \mathrm{pCi} / \mathrm{L}$. Of all the individual geologic units sampled, water in the Peters Creek Schist has the highest median radon concentration $(4,400 \mathrm{pCi} / \mathrm{L})$, and water in the ultramafic/serpentinite unit (group 6) has the lowest median radon concentration (150 pCi/L).

Some aquifers with high median concentrations of radon in water represent a large percentage of the land area in Chester County. The Peters Creek Schist, the geologic unit that underlies the second largest land area of all the geologic units in the county (about 70 square miles, or 9 percent of the county), has the highest median ground-water radon concentration $(4,400 \mathrm{pCi} / \mathrm{L})$ of all the geologic units in the county. Ground water from the Octoraro Phyllite, which underlies about 48 square miles, or 6 percent of the county, has a median ground-water radon concentration of $3,000 \mathrm{pCi} / \mathrm{L}$. The Wissahickon Schist, the geologic unit that underlies the largest land area of all the geologic units in the county (184 square miles, or about 24 percent of county area), has a median ground-water radon concentration of $1,400 \mathrm{pCi} / \mathrm{L}$.

Statistical relations were tested between radon concentrations and well characteristics, such as depth or yield, and between radon 


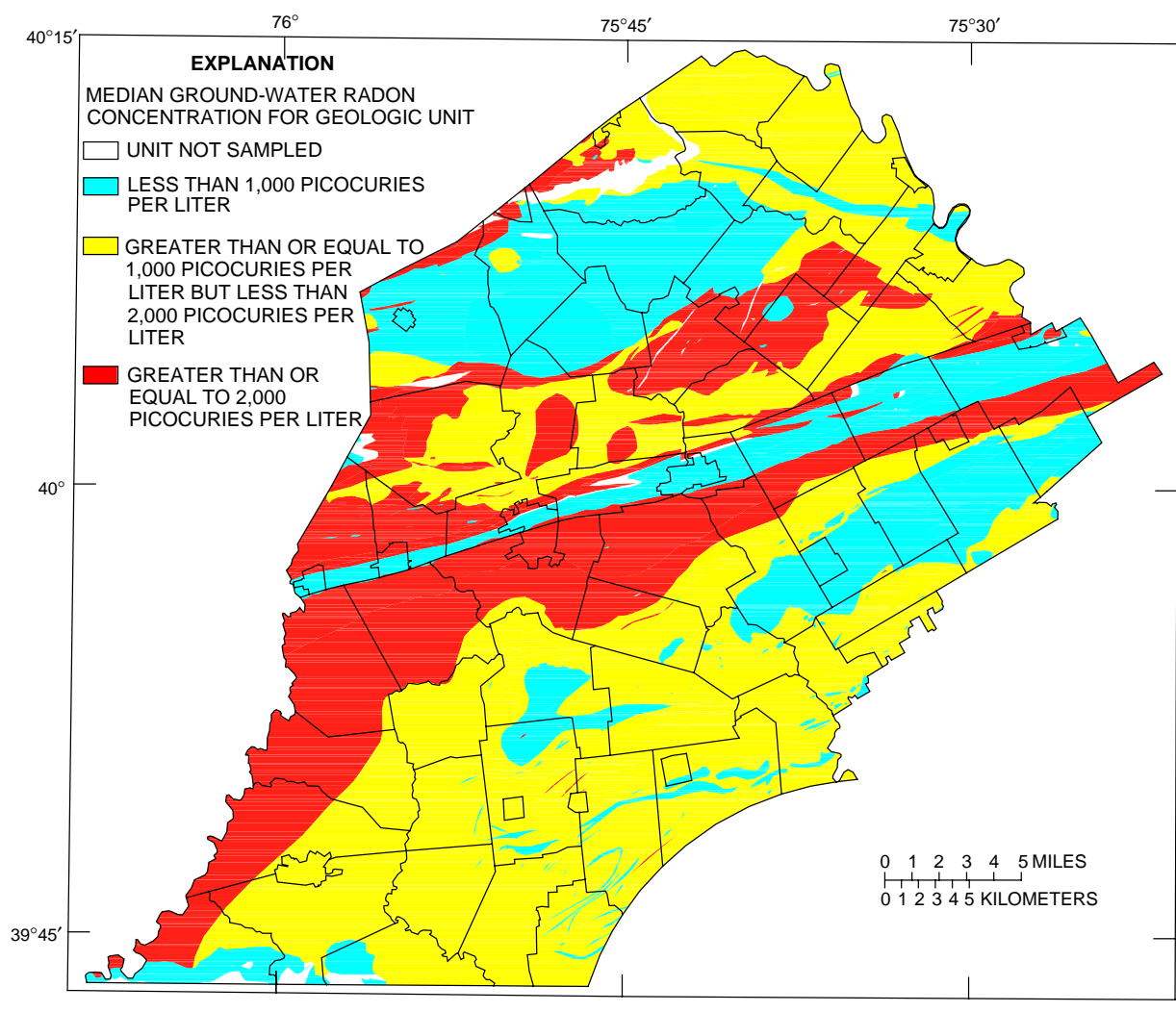

Figure 3. Concentration of radon in ground water in Chester County (Geologic map from Sloto, 1994.)

concentrations and concentrations of other chemical constituents analyzed in water samples. Radon concentrations generally did not correlate with well characteristics, the $\mathrm{pH}$ of water, or concentrations of dissolved major ions and other chemical constituents in the water samples.

\section{Why is Radon Higher in Some Areas Than in Others?}

An important factor affecting the amount of radon in ground water in Chester County is the underlying geologic unit. Many factors that affect the formation and movement of radon in ground water, such as uranium content, grain size, permeability, and the nature and extent of fracturing in the host rock, are functions of rock type (Otton, 1992). Rocks such as schist typically contain higher concentrations of uranium than rocks such as limestone; therefore, they can be expected to have higher ground-water radon concentrations.

Ground-water radon concentrations are highly variable, even within individual geologic units. The range of radon concentrations probably reflects the variable distribution of uranium or radium in the aquifer and the variable distribution of aquifer properties. Radon concentrations can range up to three orders of magnitude in water from a single geologic unit and can differ significantly from well to well locally. Some apparent differences in the observed range of radon concentrations may be because of variable sample size. The largest range of radon concentrations was in geologic units (Chickies Quartzite and Wissahickon Schist) with the largest number of samples and, therefore, the most likely to include extreme values. For geologic units with 10 or more samples, the range in radon concentrations was least in water in the Stockton Formation, Hammer Creek Formation, and the Conestoga Limestone, which may indicate that uranium or radium concentrations in water-bearing zones of these aquifers are less variable than in other geologic units.

\section{Do Radon Concentrations Vary With Time?}

Radon concentrations in ground water vary with time because of factors such as dilution by recharge or changes in contributing areas of the aquifer because of pumping (Senior, 1998). Data on temporal variability of radon in ground water is available for 28 wells that were sampled more than once. The maximum difference in radon concentrations in two samples collected from the same well was $5,100 \mathrm{pCi} / \mathrm{L}$, and the median difference in radon concentrations in two samples collected from the same well was $350 \mathrm{pCi} / \mathrm{L}$. Radon concentrations differed by more than 50 percent in water from 36 percent of the wells sampled more than once and differed by more than 100 percent (a factor of two) in water from 18 percent of the wells sampled more than once.

Thirteen wells were sampled periodically while pumping to assess radon variability during the period of sample collection. Some variability may be caused by short-term fluctuations in concentration while pumping, although this variability usually was relatively low or the result of sampling error. The difference between measured radon concentrations for samples collected during pumping (typically about 1 hour in duration) was less than 15 percent in most (85 percent) of the 18 wells sampled multiple times while pumping.

Wells sampled at regular intervals provide data on seasonal variability. Of the 10 wells that were sampled at regular intervals for at least 1 year, seasonal fluctuations in radon concentrations were observed in water samples collected from only 1 well. For most wells, radon concentrations did not exhibit a strong seasonal pattern of fluctuation (fig. 4) and also were not consistently related to changes in depth to water.

\section{What Does This Information on Radon Mean to Me As A Homeowner?}

Although radon concentrations in ground water in Chester County are more likely to be higher in certain areas relative to others, the only way to be certain of the radon concentration in the water supplied by any well is to have the water tested. Although differences in median radon concentration between geologic units are apparent, local variability is high within each unit. Therefore, prediction of radon

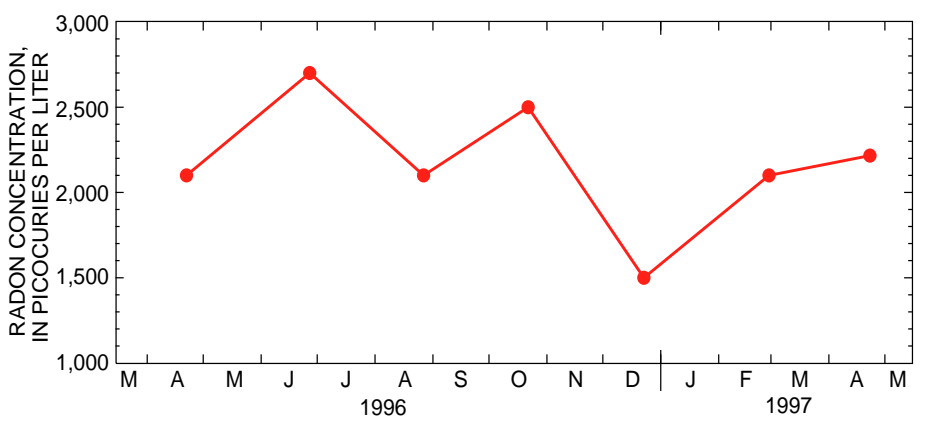

Figure 4. Variability with time in the concentration of radon dissolved in water from a well in northern Chester County. 
concentration at an individual well is difficult. The USEPA and the Surgeon General of the United States recommend that the basement, first floor, and second floor of all homes be tested for airborne radon that may be entering the home through the basement (U.S. Environmental Protection Agency and Centers for Disease Control, 1992). In homes where high indoor radon levels are measured and where water is supplied by a privately owned well, the USEPA further recommends that the well water be tested as a potential contributing source of the airborne radon. If a large percentage of the radon in your house is from your water, the USEPA recommends installing a water treatment system to remove radon. Both homes and water supplies can be treated to reduce radon levels (U.S. Environmental Protection Agency, 1992).

\section{Selected References}

Chester County Planning Commission, 1996, Water resources use and service in Chester County: Chester County Water Resources Management Plan-Phase 2, [variously paginated].

Cothern, C.R., 1987, Estimating the health risks of radon in drinking water: Journal of the American Water Works Association, v. 79, no. 4, p. 153-158.

Crawford-Brown, D.J., 1990, Analysis of health risk from ingested radon, in Cothern, C.R. and Rebers, P.A., eds., Radon, radium, and uranium in drinking water: Chelsea, Mich., Lewis Publishers, p. 17-26.

Lindsey, B.D., and Ator, S.W., 1996, Radon in ground water of the Lower Susquehanna and Potomac River Basins: U.S. Geological Survey WaterResources Investigations Report 96-4156, 6 p.

Mills, W.A., 1990, Risk assessment and control management of radon in drinking water, in Cothern, C.R. and Rebers, P.A., eds., Radon, radium, and uranium in drinking water: Chelsea, Mich., Lewis Publishers, p. 27-38.

Milry, Paul, and Cothern, C.R., 1990, Scientific background for development of regulations for radionuclides in drinking water, in Cothern, C.R., and Rebers, P.A., eds., Radon, radium, and uranium in drinking water: Chelsea, Mich., Lewis Publishers, p. 1-16.

Mose, D.G., Mushrush, G.W, and Chrosinak, C., 1990, Radioactive hazard of potable water in Virginia and Maryland: Bulletin of Environmental Contamination and Toxicology, v. 44, no. 4, p. 508-513.

Otton, J.K., 1992, The geology of radon: U.S. Geological Survey, General Interest Publications of the U.S. Geological Survey, $28 \mathrm{p}$.

Schumann, R.R., 1993, Geologic radon potential of EPA Region 3 - Delaware, Maryland, Pennsylvania, Virginia, and West Virginia: U.S. Geological Survey Open-File Report 93-292-C, 185 p

Senior, L.A., 1996, Ground-water quality and its relation to hydrogeology, land use, and surface-water quality in the Red Clay Creek Basin, Piedmont Physiographic Province, Pennsylvania and Delaware: U.S. Geological Survey Water-Resources Investigations Report 96-4288, 122 p. 1998, Radon-222 in the ground water of Chester County, Pennsylvania: U.S. Geological Survey Water-Resources Investigations Report 98-4169, 79 p.

Senior, L.A., and Vogel, K.L., 1995, Radium and radon in ground water in the Chickies quartzite, southeastern Pennsylvania: U.S. Geological Survey Water-Resources Investigations Report 92-4088, 145 p.

Sloto, R.A., 1994, Geology, hydrology, and ground-water quality of Chester County, Pennsylvania: West Chester, Pa., Chester County Water Resources Authority Water-Resource Report 2, $127 \mathrm{p}$.

Swistock, B.R., Sharpe, W.E., and Robillard, P.D., 1993, A survey of lead, nitrate and radon contamination of private individual water systems in Pennsylvania: Journal of Environmental Health, March 1993, v. 55, no. 5., p. 6-12.

U.S. Environmental Protection Agency and Centers for Disease Control, 1992, A citizen's guide to radon-The guide to protecting yourself and your family from radon (2d ed.): EPA 402-K92-001, $15 \mathrm{p}$

U.S. Environmental Protection Agency, 1992, Consumers guide to radon reduction-How to reduce radon levels in your home: EPA 402-K92-003, $17 \mathrm{p}$.

1993, Home buyer's and seller's guide to radon: EPA 402-R-93-003, $32 \mathrm{p}$. 1994, National primary drinking water standards: EPA 810-F-94-001A, 4 p. 1997, Withdrawal of the proposed national primary drinking water regulation for radon-222: Office of Ground Water and Drinking Water, Federal Register Document 97-20666.

Zapecza, O.S., and Szabo, Zoltan, 1988, Natural radioactivity in ground waterA review: U.S. Geological Survey Water-Supply Paper 2325, p. 50-57.

Ronald A. Sloto and Lisa A. Senior-1998
Where Can I Get More

\section{Information?}

More detailed information on radon in the ground water of Chester County is included in the technical report by Senior (1998). Government contacts and additional reference materials for more information about radon in water or radon in general are listed below. For current information on USEPA MCL's for radon in water, contact the USEPA Safe Drinking Water Hotline (1-800-426-4791). Contacts for individual state and county agencies are included for information on current regulations. The data on which this fact sheet is based can be obtained by contacting the USGS office in Malvern, Pa. (610-647-9008)

For additional information, contact:

District Chief

U.S. Geological Survey, WRD

840 Market Street

Lemoyne, PA 17043-1586

(717) 730-6913

Email: dc_pa@usgs.gov

Executive Director

Chester County Water Resources Authority

Government Services Center, Suite 270

P.O. Box 2747

601 Westtown Road

West Chester, PA 19380-0990

(610) $344-5400$

Environmental Health Director

Chester County Health Department

Government Services Center, Suite 295

P.O. Box 2747

601 Westtown Road

West Chester, PA 19380-0990

(610) 344-6492

\section{Contacts:}

Safe Drinking Water Hotline - USEPA, Office of Water and Drinking Water, 4601 Resource Center, $401 \mathrm{M}$ Street S.W., Washington, D.C., 20460, (800) 426-4791

United States Environmental Protection Agency, Region 3, 1650 Arch Street, Philadelphia, PA, 19103-2029, (215) 814-9800

National Radon Hotline, Box 33435, Washington, D.C., 20035-0435, (800) 767-7236

Pennsylvania Department of Environmental Protection, Bureau of Radiation Protection, Harrisburg, PA,

(800) $237-2366$ or (717) $783-3594$

Internet/World Wide Web Information:

USGS Radon Home Page:

http://sedwww.cr.usgs.gov:8080/radon

USEPA Radon Information:

http://WwW.epa.gov/iaq/radon

USEPA Radon Publications:

http://www.epa.gov/iaq/radon/pubs/index.htm/

National Safety Council, Environmental Health Center, Radon and Indoor Air Quality:

http://www.nsc.org/ehc/radon.htm

USGS Pennsylvania District Home Page:

http://pa.water.usgs.gov/ 